Kumawula, Vol. 4, No.1, April 2021, Hal 59 - 65 DOI: https://doi.org/10.24198/kumawula.v4i1.30980

ISSN 2620-844X (online)

Tersedia online di http://jurnal.unpad.ac.id/kumawula/index

\title{
PELATIHAN BERIKLAN DI FACEBOOK (FB ADS) DI PONDOK MODERN AZ ZAHRA AL GONTORY SEBAGAI MEDIA PROMOSI
}

\author{
Argiyan Dwi Pritama ${ }^{*}$, Irfan Rifai Aziz ${ }^{2}$ \\ ${ }^{1}$ Fakultas Ilmu Komputer Universitas Amikom Purwokerto \\ ${ }^{2}$ Fakultas Ilmu Komputer Universitas Amikom Purwokerto \\ *argiyandwi@amikompurwokerto.ac.id
}

\begin{abstract}
In the digital era, there are many promotion methods using the internet, and many people change the traditional promotion to using social media promotion. Although social media was originally created to help communicate and meet many people, social media can also be used to promote and sell products or services to all other social media platform users all around the world. Promotion using this social media platform is not only carried out by many business-people, and corporations too, many institutions or governments also use it as a medium of promotion. Pondok Modern Az Zahra Al Gontory which is located in Gunung Tugel, Purwokerto. It was originally a modern salaf or traditional pesantren, then this year, the board of Pondok Modern Az Zahra Al Gontory has change the modern salaf or traditional cottage to an educational institution that adopted an existing learning system from Center of Pondok Pesantren Gontor Darussalam, KMI (Kulliyatul Mu'allimin Al-Islamiyah) which applies the learning system and pattern of the Darussalam Gontor Ponorogo. Therefore, in order to develop and promote this new pesantren program it is necessary to expand the dissemination of information by advertising, one of the economical but still efficient advertising media is the social media Facebook (FB Ads) through the training that is delivered using demonstration and presentation methods which is expected to introduce more programs and promote also and can increase new students Pondok Modern Az Zahra Al Gontory.
\end{abstract}

Keywords: Ads, Facebook, Pondok Modern Az Zahra Al Gontory, Promotion, Social Media.

\begin{abstract}
ABSTRAK
Pada era digital saat ini banyak sekali kegitan promosi yang beralih menggunakan internet, salah satunya adalah promosi beralih menggunakan media sosial. Meskipun media sosial awalnya diciptakan untuk membantu berkomunikasi dan bertemu dengan banyak orang, media sosial juga bisa dimanfaatkan untuk mempromosikan dan menjual produk atau jasa kepada semua pengguna media sosial lain yang tersebar di seluruh dunia. Promosi menggunakan platform media sosial ini selain banyak dilakukan oleh para pelaku bisnis, baik yang personal maupun perusahaan, lembaga-lembaga atau instansi-instansi juga banyak yang menggunakan sebagai media promosinya. Pondok Modern Az Zahra Al Gontory yang terletak di Gunung Tugel, Purwokerto awalnya merupakan sebuah pondok modern salaf atau tradisional, kemudian pada tahun ini, pengurus Pondok Modern $\mathrm{Az}$ Zahra Al Gontory telah sepakat untuk mengubah pondok modern salaf atau tradisional ke lembaga pendidikan dengan menerapkan pola dan sistem pembelajaran yang ada di pondok menjadi KMI (Kulliyatul Mu'allimin AlIslamiyah) dengan menerapkan sistem dan pola pembelajaran Pondok Modern Darussalam Gontor Ponorogo. Oleh karena itu dalam rangka mengembangkan dan mempromosikan program pondok yang baru ini perlunya memperluas penyebaran informasi dengan beriklan, salah satu media beriklan yang ekonomis namun tetap efisien adalah dengan media sosial Facebook (FB Ads) melalui pelatihan yang disampaikan menggunakan metode demonstrasi dan presentasi. Diharapkan ke depannya dengan pelatihan ini dapat lebih mengenalkan programprogram dan mempromosikan pendaftaran santri dan santriwati di Pondok Modern Az Zahra Al Gontory ke masyarakat luas pada tahun ajaran baru sehingga dapat meningkatkan jumlah santri dan santriwati untuk belajar lebih dalam mengenai agama islam melalui pendidikan di Pondok Modern Az Zahra Al Gontory.
\end{abstract}

Kata kunci: Ads, Facebook, Pondok Modern Az Zahra Al Gontory, Promosi, Media sosial 


\section{PENDAHULUAN}

Di era informasi saat ini ditandai dengan kemudahan mengakses informasi, terutama internet, telah menjadi salah satu sarana media promosi. Metode pemasaran menjadi salah satu faktor yang menentukan tinggi rendahnya angka penjualan sebuah produk (Kusuma, 2020). Pemasaran dengan menggunakan media internet, selain efektif juga dapat menekan biaya apabila dibandingkan dengan media televisi. Bukan hanya itu, selain relatif murah jangkauannya juga merambah ke seluruh dunia. Artinya, pada era informasi saat ini komunikasi antar manusia semakin meluas dengan ditemukannya komputer, internet, smartphone dan jejaring media sosial. Saat ini terdapat jenis-jenis jejaring sosial berbentuk sebuah aplikasi yang menggolongkan fitur-fitur yang dikhususkan, misalnya jejaring sosial mengirimkan pesan langsung atau lebih sering dikenal dengan sebutan chat, jejaring sosial yang memiliki fitur audio visual, jejaring sosial mengirimkan pesan langsung dan rekam suara, jejaring sosial yang menyajikan fitur layanan pengunggahan gambar atau foto yang ditujukan kepada pengguna-pengguna jejaring sosial yang juga memiliki aplikasi tersebut (Arbi \& Dewi, 2019). Kemudian ada juga jejaring media sosial yang bisa beriklan mengenai produk maupun jasanya salah satunya adalah Facebook, lebih tepatnya layanan beriklan di Facebook atau sering disebut Facebook Ads. Facebook Ads sendiri ialah pengiklanan untuk pengguna Facebook baik yang personal, maupun yang berupa lembaga atau instansi, baik yang sedang berbisnis ataupun yang sedang ingin mempromosikan sesuatu yang akan ditayangkan di halaman pengguna Facebook baik itu menggunakan melalui perangkat komputer, tablet, ataupun smartphone.

Sedangkan platform yang sering digunakan pengguna media sosial berdasarkan dari data Hootsuite (We Are Social) di Indonesia per Januari 2020 persentase Youtube mencapai $88 \%$, WhatsApp sebesar 84\%, Facebook sebesar $82 \%$, dan Instagram sebesar $79 \%$.
Dapat disimpulkan bahwa media sosial memiliki peranan penting dalam berbagai aspek kehidupan. Dengan keberadaan media sosial yang memiliki peran penting ini pun dimanfaatkan sebagai media promosi ("Digital 2020 - We Are Social,” n.d.).

Pondok Pesantren Modern Az Zahra Al Gontory yang terletak di Gunung Tugel, Purwokerto merupakan sebuah Lembaga pendidikan yang mendidik kader-kader umat yang dibangun atas dasar nilai Iman, Islam, dan Ihsan secara Kaafah. Berawal dari sebuah Majlis Ta'lim Al Istiqomah yang terletak di Grumbul Gunung Tugel kemudian pada tahun 2010 didirikanlah sebuah Pondok Pesantren Az-Zahra dan Madrasah Diniyah sebagai lembaga pendidikannya. Sejak awal berdiri pada tahun 2010 hingga saat ini dan seterusnya Pondok Pesantren Modern Az-Zahra Gunung Tugel terus melakukan inovasi dalam penddikan, budaya dan ekonomi guna menciptakan generasi umat yang bertakwa, militan, dan berpengetahuan luas. Pada tahun ini, 2020, manajemen Pondok Modern Az Zahra Al Gontory telah sepakat untuk mengubah pola dan sistem pembelajaran yang ada di pondok menjadi KMI (Kulliyatul Mu'allimin Al-Islamiyah) dengan menerapkan sistem dan pola pembelajaran Pondok Modern Darussalam Gontor Ponorogo. Selaras dengan visi dan misi Pondok Pesantren ini dalam pengembangan bentuk baru sebagai Pondok Modern Az Zahra Al Gontory perlunya strategi promosi yang baru untuk memperkenalkan pondok secara umum, dan memperkenalkan program-program yang ada di dalamnya secara khusus kepada masyarakat luas melalui media sosial.

Media jejaring sosial pada saat ini sangat mempermudah penggunanya dengan adanya smartphone yang dapat mengakses layananlayanan di internet (Arbi \& Dewi, 2019). Disisi lain, setiap harinya jutaan pengguna mengungkapkan minat mereka di media sosial Facebook dalam setiap unggahanannya, yang kemudian digunakan untuk kampanye 
pemasaran iklan bertarget (Araújo, Mejova, Weber, \& Benevenuto, 2017).

Pada penelitian sebelumnya yang dilakukan oleh M. Silva yang berjudul "Facebook Ads Monitor: An Independent Auditing System for Political Ads on Facebook" mengemukakan bahwa mulanya beriklan di media sosial dianggap sedikit tabu di masyarakat, karena semakin sulit untuk melacak statistik penting terkait populasi objek sasaran yang dituju yang tersebar secara geografis, yang mengakibatkan kurangnya data yang dapat diandalkan dan mutakhir (Silva et al., 2020). Perbedaannya adalah pada pelatihan ini Facebook akan digunakan sebagai alat bantu melacak statistik target pasar sesuai target informasi yang akan disampaikan kepada calon wali santri yang dituju oleh Pondok Modern Az Zahra Al Gontory. Seperti halnya pada penelitian Lia Herliani dalam "Analisis Pemanfaatan Situs Jejaring Sosial Facebook Sebagai Media Promosi Anggota Busam (Bubuhan Samarinda)" yang memanfaatkan media sosial untuk mempromosikan sebuah organisasi masyarakat (Herliani, 2015).

Oleh karena itu Pondok Pesantren Salaf menjadi Pondok Modern Az Zahra Al Gontory menggunakan sebuah media promosi yang efektif di era teknologi saat ini dari sebelumnya hanya menggunakan metode tradisional sekarang akan menambah strateginya menggunakan media sosial Facebook untuk menjangkau setiap lapisan masyarakat, terutama calon santri dan santriwati dan juga calon orang tua santri dan santriwati. Diharapkan dengan menggunakan strategi promosi melalui media sosial ini, Pondok Modern Az Zahra Al Gontory lebih dikenal masyarakat luas dan bertambah kuantitas santri dan santriwati dan kualitas santri dan santriwati di dalamnya.

Dengan kegiatan pengabdian ini, tim dosen Universitas Amikom Purwokerto berusaha memberikan pelatihan bagaimana beriklan di media sosial Facebook. Hal ini akan sangat membantu Pondok Modern Az Zahra Al Gontory dalam mempromosikan program- program pendidikan islami didalamnya. Selain itu, dengan beriklan di Facebook, target pasar yang diinginkan Pondok Modern Az Zahra Al Gontory dapat menjangkau para target, yaitu para calon orangtua santri dan satriwati didaerah atau kabupaten yang berdekatan dengan lokasi Pondok Modern Az Zahra Al Gontory.

\section{METODE}

Metode yang digunakan pada pengabdian ini adalah metode Direct Instruction, di mana dalam Afandi, Chamalah, dan Wardani di bukunya yang berjudul "Model Dan Metode Pembelajaran Di Sekolah" menuturkan menurut Killen dalam DEPDIKNAS (Afandi, Chamalah, \& Wardani, 2013), pembelajaran langsung atau Direct Instruction merujuk pada berbagai teknik pembelajaran ekspositori (pemindahan pengetahuan dari guru kepada murid secara langsung, misalnya melalui ceramah, demonstrasi, dan tanya jawab) yang melibatkan seluruh kelas. Metode Direct Instruction akan menekankan pada demonstrasi dan presentasi kepada pihak manajemen Pondok Modern Az Zahra Al Gontory serta para tenaga pengajar dengan total peserta kurang lebih 15 peserta dari Pondok Modern Az Zahra Al Gontory yang akan diberikan bekal pengetahuan dalam mempromosikan Pondok Modern Az Zahra Al Gontory di media sosial.

\section{HASIL DAN PEMBAHASAN}

Pelatihan merupakan sekumpulan aktivitas yang memiliki tujuan untuk meningkatkan kinerja dalam bekerja dengan mempertimbangkan masukan, proses, keluaran serta dampaknya (Susanti, Gunawan, \& Sukaesih, 2019). Pada pelatihan ini, dihadiri oleh asatidz dan manajemen dari Pondok Modern Az Zahra Al Gontory yang belum pernah bahkan beriklan di media sosial Facebook. Metode pemberian materi yang pertama adalah dengan metode ceramah dengan pembahasan 2 materi inti dari Facebook $A d s$ ini. 
A. Pemberian materi teori Facebook Ads dengan metode ceramah dan presentasi

1. Pengantar Facebook Ads

Salah satu metode pemasaran atau promosi dalam internet adalah dengan beriklan. Facebook merupakan salah satu media sosial terbesar di dunia dengan ratusan juta pengguna aktif diseluruh dunia. Kelebihan itulah yang membuat Facebook sangat diminati para pengiklan untuk menggunakan layanannya yaitu Facebook Ads, sehingga Facebook merupakan alat atau platform yang sangat cocok untuk melakukan pemasaran.

Membuat iklan di Facebook bisa dilakukan secara langsung dari tampilan depan akun personal atau akun fanpage atau bisa juga langsung dari bisnis manager untuk membuatnya langsung melalui akun iklan bisnis.

\section{Facebook Fanpage pada Pondok Modern} Az Zahra Al Gontory

Dalam pelatihan ini, unggahan yang akan diiklankan berasal dari fanpage Pondok Modern Az Zahra Al Gontory yaitu berupa unggahan gambar maupun video. Ada beberapa kriteria unggahan foto maupun video yang dapat diiklankan dengan cepat dan disetujui oleh pihak Facebook, salah satunya adalah untuk gambar yang tidak banyak mengandung teks.

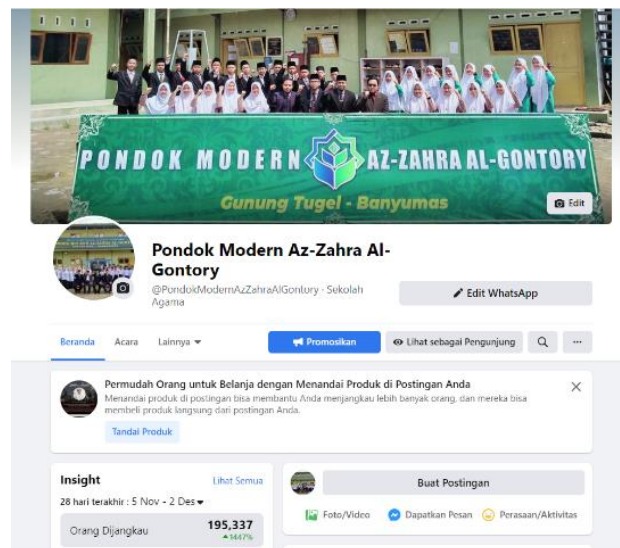

Gambar 1. Fanpage Pondok Modern Az Zahra Al Gontory
B. Pemberian materi praktik menggunakan metode demonstrasi langsung kepada peserta

Selanjutnya memasuki sesi demonstrasi secara langsung bersama para asatidz dan manajemen pondok untuk memberikan langkah-langkah yang benar dan bertarget yang sudah disepakati yaitu menyasar ke calon Wali Santri/Santriwati Pondok Modern Az Zahra Al Gontory, yang pertama langkahnya yaitu:

1. Memilih unggahan yang akan diiklankan Seperti yang sudah dijelaskan di atas, unggahan yang akan diiklankan adalah berupa unggahan gambar maupun video. Caranya adalah tinggal klik pada unggahannya, yaitu tombol "Promosikan Unggahan".

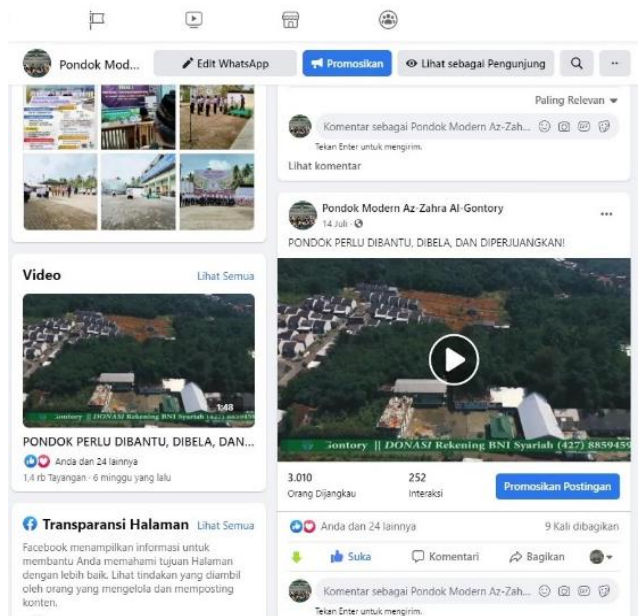

Gambar 2. Unggahan Pondok Modern Az Zahra Al Gontory yang diiklankan

\section{Mengisi saldo Facebook Ads}

Sebelum melanjutkan beriklan, untuk pembayarannya adalah dengan cara mengisi saldo di Facebook $A d s$ melalui alamat https://www.Facebook.com/manage.

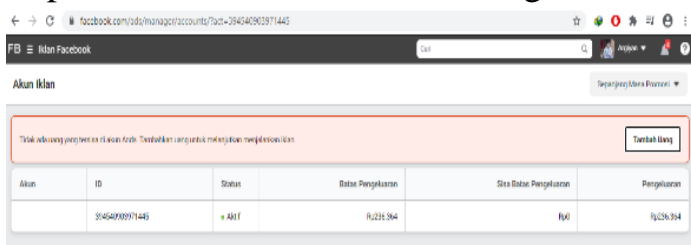

Gambar 3. Pengisian saldo untuk beriklan di Facebook 
Pada halaman ini, silakan untuk menambahakan uang melalui tombol "Tambahkan Uang" yang nantinya akan muncul halaman memilih pilihan pembayaran meliputi, kredit, debit, transfer bank, dan lain-lain. Jika sudah dipilih, nanti akan muncul halaman yang berisi cara pengiriman beserta nomor virtual pembayarannya untuk dilakukan pengiriman saldonya kedalam Facebook Ads. Setelah sudah mengisi saldo baru ke langkah yang sudah dijelaskan di atas yaitu dengan mengklik tombol promosikan Unggahan.

\section{Tentukan tujuan iklan}

Facebook Ads mempunyai beragam jenis tujuan untuk optimasi sebuah iklan. Tujuan ini lah yang akan memaksimalkan iklan sesuai dengan 'action' audiens yang pengiklan targetkan. Misalnya dengan memilih tujuan Engagement, maka Facebook akan menayangkan iklan kepada pemirsa yang mempunyai kecenderungan untuk like, komen, dan mengirimkan pesan. Jika tujuannya Traffic, maka Facebook akan menayangkan iklan kepada audiens yang mempunyai kecenderungan untuk mendapatkan lebih banyak tayangan video.

\section{Gambar 4. Tujuan iklan Facebook}

\section{Tentukan target pemirsa}

Setelah menentukan jenis tujuan, selanjutnya akan dimulai menentukan target penonton yang sesuai dengan unggahan yang diiklankan.

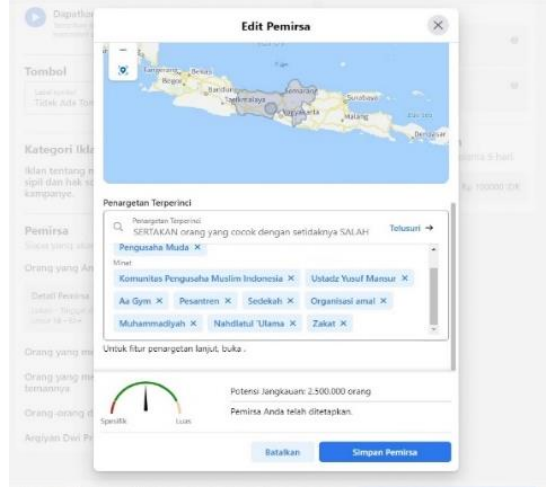

Gambar 5. Penargetan iklan Facebook Ads

- Lokasi:

Wilayah yang ingin ditargetkan. Bisa diisi dengan negara, provinsi atau kota.

- Usia:

Usia target penonton.

- Jenis kelamin:

Jenis kelamin target penonton.

- Bahasa:

Bahasa yang digunakan target penonton (bisa dibiarkan kosong jika tak ingin spesifik menargetkan audiens berdasarkan bahasa yang digunakan).

- Penargetan Terperinci:

Pada bagian ini juga salah satu yang paling menentukan target penonton dari unggahan yang kita ikankan. Bagian ini bisa diisi dengan Interest (minat atau ketertarikan target penonton di Facebook. Contohnya mengiklankan unggahan Pondok Modern Az Zahra Al Gontory ini, maka bisa mengisikan halhal yang paling berkaitan dengan produk atau basis yang kita iklankan seperti yang berhubungan dengan unggahan Pondok Modern Az Zahra Al Gontory adalah muslim, tokoh masyarakat, komunitas, dan lain sebagainya. Ini erat kaitannya dengan Behavior (perilaku audiens) dan Demographic (Demografis, misalnya menargetkan orang- orang yang sudah menikah).

5. Menentukan Budget Iklan Facebook Ads

Dalam beriklan di Facebook salah satu keunggulannya adalah durasi dan jangkauan iklannya bisa disesuaikan dengan budget 
yang dimiliki sehingga bisa menyesuaikan dengan anggaran yang dialokasikan untuk promosi. Selain itu juga bisa menentukan penempatan iklannya. Yang menarik adalah penempatan di Instagram untuk unggahan yang kita iklankan, di mana nantinya pada media sosial Instagram iklan nya pun akan akan muncul selain di Facebook.

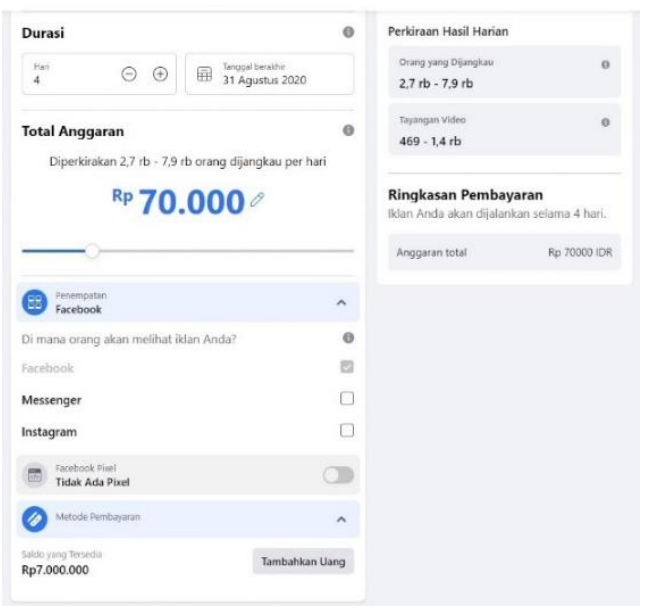

Gambar 6. Penentuan budget iklan

\section{Memantau iklan Facebook}

Jika semua langkah sudah dilalui untuk beriklan di Facebook, nantinya akan bisa kita pantau langsung melalui halaman https://www.Facebook.com/manage juga.

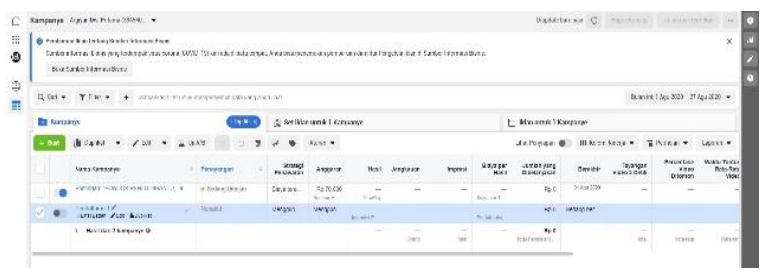

Gambar 7. Unggahan yang sudah berhasil diiklankan di Facebook Ads

Atau bisa lebih terperincinya bisa di lihat dalam detail Facebook Ads manage. Dari target yang sudah kita tentukan, nanti akan terlihat seberapa tercapainya target yang diinginkan.

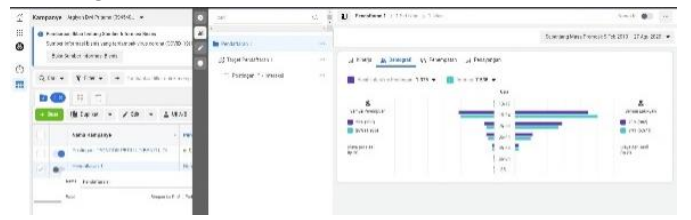

Gambar 8. Pantauan kinerja iklan

\section{SIMPULAN}

Dari hasil dari pelatihan mengiklankan unggahan di Facebook Ads ini pada Pondok Modern Az Zahra Al Gontory, disimpulkan bahwa manajemen dan tenaga pengajar (asatidz) dari Pondok Modern Az Zahra Al Gontory menerima dengan baik materi yang disampaikan melalui metode presentasi dan demonstrasi. Hal ini dibuktikan dengan berhasilnya iklan dijalankan dari unggahan Fanpage Facebook dari Pondok Modern Az Zahra Al Gontory yaitu "Video Profil Pondok Modern Az Zahra Al Gontory" yang menjadi unggahan yang diiklankan. Oleh karena itu, manajemen dan tenaga pengajar (asatidz) dari Pondok Modern Az Zahra Al Gontory sudah siap dalam beriklan di Facebook dengan unggahan-unggahan selanjutnya, sebagai contoh poster tahun ajaran baru atau unggahan donasi kepada Pondok Modern Az Zahra Al Gontory yang bisa dipromosikan untuk menjadi ladang pahala bagi para donatur.

\section{UCAPAN TERIMAKASIH}

Terimakasih kepada pihak Pondok Modern Az Zahra Al Gontory, pimpinan pondok Ustd. Anwar Mutaqin, para asatidz dan para santri tentunya yang sudah sangat antusias dalam program pengabdian kepada masyarakat ini. Semoga seluruh keluarga besar Pondok Modern Az Zahra Al Gontory terus diberi kesehatan dan pondok berkembang pesat serta menghasilkan para lulusannya pemimpin-pemimpin indonesia yang berkualitas dimasa depan.

\section{DAFTAR PUSTAKA}

Afandi, M., Chamalah, E., \& Wardani, O. P. (2013). Model Dan Metode Pembelajaran Di Sekolah. In Perpustakaan Nasional Katalog Dalam Terbitan (KDT) (Vol. 392). https://doi.org/10.1007/s00423006-0143-4

Araújo, M., Mejova, Y., Weber, I., \& Benevenuto, F. (2017). Using Facebook Ads audiences for global lifestyle disease surveillance: Promises and limitations. WebSci 2017 - Proceedings of the 2017 
ACM Web Science Conference, 253-257. https://doi.org/10.1145/3091478.3091513

Arbi, F., \& Dewi, S. I. (2019). Pengaruh Media Sosial Instagram Terhadap Minat Fotografi Pada Komunitas Fotografi Kamera Indonesia Malang. JISIP: Jurnal Ilmu Sosial Dan Ilmu Politik, 6(2), 6974.

Digital 2020 - We Are Social. (n.d.).

Herliani, L. (2015). ANALISIS

PEMANFAATAN SITUS JEJARING

SOSIAL FACEBOOK SEBAGAI MEDIA PROMOSI ANGGOTA BUSAM ( BUBUHAN SAMARINDA )

Perumusan Masalah. EJournal Ilmu Komunikasi, 3(4), 212-224.

Kusuma, D. A. (2020). Peningkatan Penjualan Dandang Menggunakan Metode Viral Marketing di Desa Cileunyi Kulon. Kumawula: Jurnal Pengabdian Kepada Masyarakat, 3(2), 197. https://doi.org/10.24198/kumawula.v3i2. 26267

Silva, M., Santos De Oliveira, L., Andreou, A., Vaz De Melo, P. O., Goga, O., \& Benevenuto, F. (2020). Facebook Ads Monitor: An Independent Auditing System for Political Ads on Facebook. The Web Conference 2020 - Proceedings of the World Wide Web Conference, WWW 2020, 224-234.

https://doi.org/10.1145/3366423.3380109

Susanti, S., Gunawan, W., \& Sukaesih, S. (2019). Pengembangan Pemasaran Bordir dan Kelom Geulis Tasikmalaya Melalui Media Sosial. Jurnal Kumawula: Jurnal Pengabdian Kepada Masyarakat, 2(3), 248-261.

https://doi.org/http://10.24198/kumawula. vli3.25256 